\title{
SAFETY MONITORING BY MEANS OF SENSOR NETWORKS DISTRIBUTED WITHIN THE FOSSA SITE PLAN
}

\author{
E. Laurini' ${ }^{1}$, M. Rotilio ${ }^{1}$, P. De Berardinis ${ }^{1}$, B. Tudini ${ }^{1}$ and V. Stornelli ${ }^{2}$ \\ 1: University of L'Aquila, DICEAA-Department of Civil, Construction-Architectural and Environmental Engineering \\ elelaurini@yahoo.it, (marianna.rotilio, pierluigi.deberardinis@univaq.it, benedetta.tudini@alice.it) \\ 2: University of L'Aquila, Department of Industrial and Information Engineering and Economics - DIIIE
}

(vincenzo.stornelli@univaq.it)

KEY WORDS: Construction Site; Construction Site Plan; Monitoring; Sensors; Programming; Earthquake.

\begin{abstract}
:
The seismic event of 6 April 2009 has inevitably left its mark on the history of the entire territory of L'Aquila (Italy), completely devastating the town and much of the province. Within such frantic and extensive reconstruction activity, the resulting construction works could not but draw attention to some issues of fundamental importance such as coordinated planning, safety, respect for the rules and above all the rebirth of the territory. This research is aimed at drawing up the site plan for Fossa, a municipality in the Province of L'Aquila and not far from the region capital of Abruzzo, Italy. The main objective is to create a monitoring standard by means of a dedicated sensors network and detailed strategies in order to coordinate, guide and support the single actions of intervention through design behaviours and highly technological tools. The Plan is configured as a tool for participatory planning, with the active involvement of planners, companies and citizens, whose common goal is the preservation of the identity of locations, the mitigation of seismic risk and the enhancement of the cultural heritage of the Municipality of Fossa. Implementation of this work is the application of technological systems for construction site monitoring: a concrete response to the growing demand for organized management of the construction process on site and safety in the workplace can be achieved through the use of systems and rational control and management procedures that include the use of innovative technologies.
\end{abstract}

\section{INTRODUCTION}

Following the disastrous event of the earthquake on 6 April 2009 , which upset not only the moral but also territorial, economic and construction equilibrium, we found ourselves faced with a need that had never occurred before: work concurrently on such a large territory in order to recover it. Initially, the immediate housing emergency was dealt with, then the problem of reconstruction came up, which affected and continues to affect not only the town of L'Aquila, but a much wider area.

When one has to deal with such a large territory and with such a high value historical heritage, it is essential to use a tool such as the construction site plan, to ensure coordination among companies, foresee crisis situations, ensure the safety and health of the population and workers, optimize resources, reduce environmental impact $[1,2]$ and, finally, test technologies that are not yet widespread [3, 4].

The aim of the plan is to cooperate, govern and certify the individual actions through an integrated approach. It is configured as a participatory planning tool, with the active involvement of planners, companies and citizens, whose common goal is the preservation of the identity of locations, the mitigation of seismic risk and the enhancement of local cultural heritage [1]

The importance of adopting a holistic approach applied to complex scenarios such as those mentioned above has been pioneered by the legislator through Law No. 77 of 24 June 2009, converting the Legislative Decree of 28 April 2009, No. 39 , which involved the reconstruction of the historic centres of the municipalities of the crater through reconstruction plans, whose objectives and content, including the construction site plan, are defined by the Decree of the Deputy Commissioner for
Reconstruction-President of the Region of Abruzzo No. 3 of 9 March 2010 [5-7].

The plan proposes to be an opportunity to rethink construction site intervention of each building, integrated with the rest of the town, in order to pursue the reconstruction of the urban settlement, the redevelopment of the built-up area and finally the return of the population to their homes.

Application of the plan to the case study of the Municipality of Fossa (AQ) required a preliminary study of the territory.

In this document, we have focused on the part of the study that concerns the automation aspect of the safety verification process. Building Information Modelling, geografic information system, augmented reality, UAV photogrammetry are some of the new paradigms in the construction industry [8-12]. Currently there are dynamic platforms connected to sensors (probes, detectors) and Personal Protection Equipment (PPE) through smart equipment designed for the purpose with innovative technologies. Among the smart PPE, the smart helmet is now available, a helmet solution for construction sites developed with BIM technology that allows the real-time and remote reproduction within the building site (figure 1), of the project developed in BIM (Building Information Modeling), for the evaluation of the position of the worker wearing [13] it and of the materials $[14,15]$. Each operator's personal badge [16] can also be used for detection on the means of work equipped with GPS for recognition and "stamping" and allows identification of the geographical location and data collection through special portals (Arcoda information technology or Landmarc location-sensing system [17]) for use, obtaining attendance mapping and schedules control. And all these systems could be integrated to manage an overall project [18]. The aspect of this Construction Site Plan relating to the remote monitoring of certain safety aspects is highly topical [19]. In 
addition, the Remote Plan was further implemented during the drafting phase of the project, following the worldwide health emergency due to the spread of the Covid-19 virus, adapting the safety rules within the construction sites to contain the virus. Therefore, the pandemic aspect was also addressed through monitoring of some vital and spacing parameters.

Next section illustrates the research background, followed by the illustration of the research, sections 3., 4. and 5., the discussion, section 6 . and conclusions, section 7 .

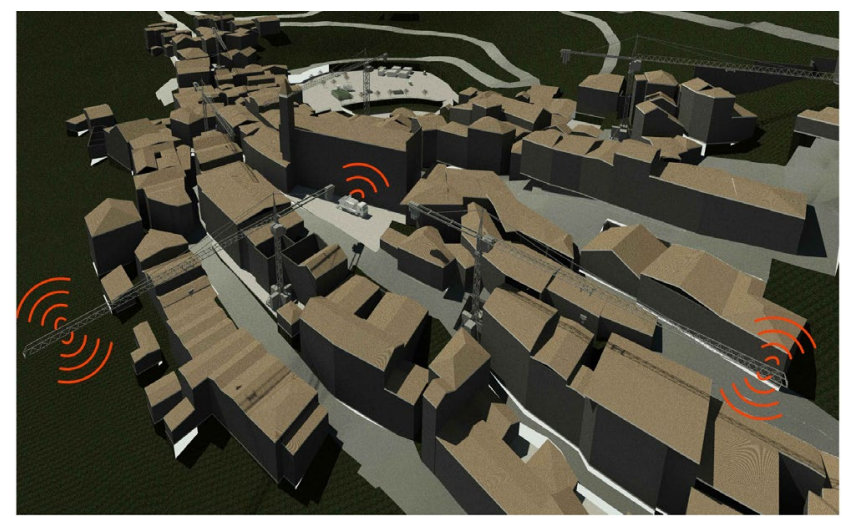

Figure 1. Rendered view. The figure represents the BIM model of Fossa with the preparations for the construction site (crane, common storage area, etc.)

\section{RESEARCH BACKGROUND}

In this section an overview of studies in the field of Internet of Things (IoT) applied to the construction industry from 1995 to today is presented (Tab. 1 below). The main fields of study are the following:

- Monitoring of building materials [4, 13, 25, 26];
- Development of technologies for locating objects inside buildings [17] and workers [16];

- $\quad$ Project management [18];

- System for preventing construction site accidents [21, 22] an fire risk [19];

- Building monitoring $[23,14]$ and Life cycle building [14];

- Complex scenarios ad rock monitoring [28, 24];

- Construction site monitoring [11,31];

- Digital Twin [29, 30, 32]

With this analysis it is evident that the interest in the Internet of Things topic is transversal in many fields of the construction industry, from design to monitoring. Furthermore, the temporal analysis of the references shows how this interest has grown over the years. However, the studies analyzed show a focus on single aspects with the exception of the most recent ones that focus on the theme of the digital twin and on the overall automation also with the use of the IoT. However, the latter are still few within the construction site field, so the research gap to be implemented is evident. And the study illustrated in this article is part of this latest and innovative field of study which aims at overall automation and at integrated approaches into the construction site.

The proposed study makes to implement the rationality and quality of the construction process and the safety of operators, even in a pandemic condition, possible. Therefore it contributes to the implementation of the research gap highlighted.

\begin{tabular}{|c|c|c|c|}
\hline Reference / Year & Aim of the research & Results & Field \\
\hline$[13], 1995$ & $\begin{array}{l}\text { To provides construction industry owners and contractors with } \\
\text { information about enhancing their operations using radio } \\
\text { frequency identification (RFID) technology }\end{array}$ & $\begin{array}{l}\text { RFID did show promise of being a beneficial technology as it relates to the } \\
\text { materials receiving process }\end{array}$ & Materials in construction site \\
\hline [17], 2004 & $\begin{array}{l}\text { To present LANDMARC, a location sensing prototype system that } \\
\text { uses Radio Frequency Identification (RFID) technology for locating } \\
\text { objects inside buildings }\end{array}$ & $\begin{array}{c}\text { Authors demonstrate that active RFID is a viable and cost-effective } \\
\text { candidate for indoor location sensing and they point out three major } \\
\text { features that should be added to make RFID technologies competitive in } \\
\text { this new and growing market }\end{array}$ & Indoor location sensing \\
\hline$[18], 2006$ & $\begin{array}{c}\text { To propose an application model that can be used to derive an } \\
\text { RFID application method by reflecting the characteristics of various } \\
\text { works }\end{array}$ & Defining a method to manage the overall project progress & $\begin{array}{c}\text { Project } \\
\text { management }\end{array}$ \\
\hline [19], 2007 & $\begin{array}{l}\text { To collect and return building rescue drawings and fire control } \\
\text { information to rescue team in accident scene, using RFID }\end{array}$ & $\begin{array}{c}\text { To integrate the fire control related data, to accelerate fire control } \\
\text { operation, assist the responsible agency to manage the database and } \\
\text { provide immediate inquiry capability through internet }\end{array}$ & Urban centre \\
\hline [21], 2009 & $\begin{array}{l}\text { To describes the development of a personal warning system for } \\
\text { preventing construction site accidents involving workers and } \\
\text { heavy equipment }\end{array}$ & $\begin{array}{l}\text { An experimental prototype device for sending a message from a server } \\
\text { computer to a smart-phone was made under a wireless local area network }\end{array}$ & Construction site \\
\hline [23], 2012 & $\begin{array}{c}\text { This paper focuses on building monitoring systems that are } \\
\text { essentials to identify and improve the building energy } \\
\text { performances in an efficient way }\end{array}$ & $\begin{array}{c}\text { Authors show the different levels of optimization and the importance to } \\
\text { take into account the physical layer performances in the MAC layer } \\
\text { assessment }\end{array}$ & $\begin{array}{l}\text { Building } \\
\text { monitoring }\end{array}$ \\
\hline$[25], 2012$ & $\begin{array}{l}\text { To develop a system of concrete monitoring via wireless signal } \\
\text { transmission }\end{array}$ & $\begin{array}{l}\text { A new measurement technique was developed that enables direct, real- } \\
\text { time measurements and continuous monitoring of concrete internal } \\
\text { temperature and humidity via wireless signal transmission }\end{array}$ & Materials monitoring \\
\hline [22], 2013 & $\begin{array}{c}\text { The objective is to analyze the proactively preventive information } \\
\text { requirement of struck-by-falling-object accidents and propose an } \\
\text { integrated information management model using a ZigBee RFID } \\
\text { sensor network to fulfill these requirements }\end{array}$ & $\begin{array}{l}\text { To provide a possible approach for tracking struck-by-falling-object } \\
\text { accidents based on real-time information for proactive prevention and } \\
\text { could serve as a foundation for further study }\end{array}$ & Construction site \\
\hline$[16], 2014$ & $\begin{array}{c}\text { The development of a location system for workers using RFID } \\
\text { technology }\end{array}$ & $\begin{array}{l}\text { The authors confirmed the possibility of the location system with RFID } \\
\text { technology, and mentioned the factors necessary to develop for further }\end{array}$ & $\begin{array}{c}\text { Workers } \\
\text { Localization in construction site }\end{array}$ \\
\hline$[14], 2015$ & $\begin{array}{c}\text { To present a review of RFID applications in the construction } \\
\text { industry, pointing out the existing developments, limitations and } \\
\text { gaps }\end{array}$ & $\begin{array}{l}\text { The paper presents the establishment of the RFID technology in four main } \\
\text { stages of the lifecycle of a facility: planning and design, construction and } \\
\text { commission and operation and maintenance }\end{array}$ & $\begin{array}{l}\text { Lifecycle of a facility (also in } \\
\text { construction site) }\end{array}$ \\
\hline [26], 2015 & $\begin{array}{l}\text { To solve the problem of application of sensors inside a structure } \\
\text { that is the need of powerand data-cables to be connected to a } \\
\text { measurement device which is expensive and not practical }\end{array}$ & $\begin{array}{l}\text { Embedded RFID based sensors with minimum need of power supply that } \\
\text { measure and store data of temperature, humidity and corrosion rate in } \\
\text { reinforced concrete structure }\end{array}$ & Materials monitoring \\
\hline
\end{tabular}




\begin{tabular}{|c|c|c|c|}
\hline Reference / Year & Aim of the research & Results & Field \\
\hline [24], 2017 & $\begin{array}{l}\text { To present an innovative sensing system able to recognize a rock } \\
\text { fall event and to monitor the structural parameters of a falling rock } \\
\text { protection barrier }\end{array}$ & $\begin{array}{l}\text { The architecture provides information about the vibration and the } \\
\text { inclination of the falling rock protection barrier. The novel system is } \\
\text { currently working on a gabion protecting mesh installed in the south of } \\
\text { Italy }\end{array}$ & Rock monitoring \\
\hline [29], 2017 & $\begin{array}{l}\text { To bridge the gap between design and } \\
\text { manufacturing and to mirror the real and virtual worlds }\end{array}$ & $\begin{array}{l}\text { To propose a comprehensive reference model based on the concept of } \\
\text { Skin Model Shapes, which serves as a digital twin of the physical product in } \\
\text { design and manufacturing. In this regard, model conceptualization, } \\
\text { representation, and implementation as well as applications along } \\
\text { the product life-cycle are addressed }\end{array}$ & Digital twins in production \\
\hline [28], 2018 & $\begin{array}{l}\text { The paper deals with the definition and analysis of a complete } \\
\text { electronic system for the detection and monitoring of stability } \\
\text { characteristics in complex scenarios such as structural elements or } \\
\text { environmental events }\end{array}$ & $\begin{array}{l}\text { It has been successfully adopted to detect rock fall events on protection } \\
\text { barriers, as well as to monitor landslides or the integrity of structures like } \\
\text { bridges and buildings. }\end{array}$ & Complex scenarios monitoring \\
\hline$[4], 2019$ & $\begin{array}{l}\text { The connection between the contents of } 4.0 \text { Industry and the } \\
\text { information sharing with BIM design, through the insertion into a } \\
\text { single data container (black box), of all the sensors inherent to the } \\
\text { entire building process, to monitor the building from the early } \\
\text { construction phases and obtain a precise history about it }\end{array}$ & the black box and the sensor system have been designed & Materials in construction site \\
\hline [11], 2019 & $\begin{array}{l}\text { To illustrate a methodology that, starting from a series of } \\
\text { preliminary surveys, supports the development of the program of } \\
\text { reconstruction of a historic urban centre hit by an earthquake } \\
\text { event; } \\
\text { to prevent problems, interferences and criticalities in order to } \\
\text { increase the safety and rationality of the entire reconstruction } \\
\text { process } \\
\end{array}$ & $\begin{array}{l}\text { UAV photogrammetry helped to inspect the real situation in a post- } \\
\text { earthquake scenario in order to planning the reconstruction phases }\end{array}$ & Urban centre in construction site \\
\hline$[30], 2019$ & $\begin{array}{l}\text { To aim to study the expansion of the digital twin in including } \\
\text { building life cycle management and explore the benefits and } \\
\text { shortcomings of such implementation }\end{array}$ & Realize a digital twin of an office building facade element & $\begin{array}{l}\text { Digital twins in building life } \\
\text { management }\end{array}$ \\
\hline$[31], 2019$ & To improve efficiency and productivity on construction sites & $\begin{array}{l}\text { Analyses of case studies: real-time monitoring of the safety of temporary } \\
\text { structures, and tracking the exact moment a concrete slab has cured }\end{array}$ & Construction site monitoring \\
\hline$[32], 2020$ & $\begin{array}{l}\text { To synthesizes the current state of practice of Digital Twin in } \\
\text { construction by reviewing the } \\
\text { extant literature }\end{array}$ & $\begin{array}{l}\text { The research proposes a framework that classifies the level of integration } \\
\text { in construction into } \\
\text { three subcategories namely: Digital Model, Digital Shadow, and Digital } \\
\text { Twin }\end{array}$ & Digital twins in construction \\
\hline
\end{tabular}

Table 1: An overview of studies in the field of Internet of Things applied to the construction industry

\section{SENSOR APPLICATION METHODOLOGICAL APPROACH}

The Construction Site Plan is based on the assumption that in a town or district to be redeveloped and/or renovated, a single large construction site can be identified and managed as such with an unambiguous approach (figure 2). Due to the complexity of the urban fabric on which the town stands and the size of the intervention, it was necessary to introduce a remote monitoring system for the safety of the construction site, since a workplace of this size generates such interference that it is necessary to smartly manage the safety of users in order to limit subjective human choices. Issues noted also by other authors [20-22].

The territory of Fossa, Italy, borders to the west with the Municipality of Ocre, to the south with the municipality of Sant'Eusanio, to the east with the municipality of Poggio Picenze and to the north-east with two hamlets of the municipality of L'Aquila (Monticchio and Onna). The town has a very marked morphological peculiarity: it developed at the foot of Monte Circolo creating a sinkhole in correspondence with the main square. On the ridge there is a landslide and a hydrogeological constraint, which certifies the danger of the north-eastern slope of Monte Circolo. This aspect was of fundamental importance in the elaboration of the Plan, since it represents one of the major criticalities encountered and a crucial aspect for the choice of the Plan strategies and monitoring.

In the proposed safety monitoring architecture the approach is to the design of a sensor network system for remote monitoring $[23,24]$ that first starts by identifying what needs to be monitored and why (figure 3 ). In this specific case, the mission is to minimize risk by increasing the control devices through a network of wireless sensors, using available devices, applied to vehicles and equipment on site, which are in turn equipped with RFID systems [25, 26, 27].

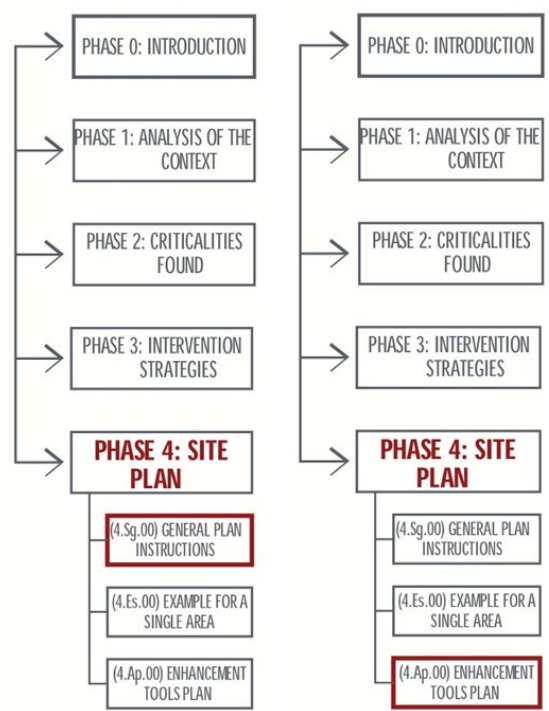

Figure 2. Methodological path. The flow chart rappresent the methodological approach to research. The topics covered in this text are highlighted in red.

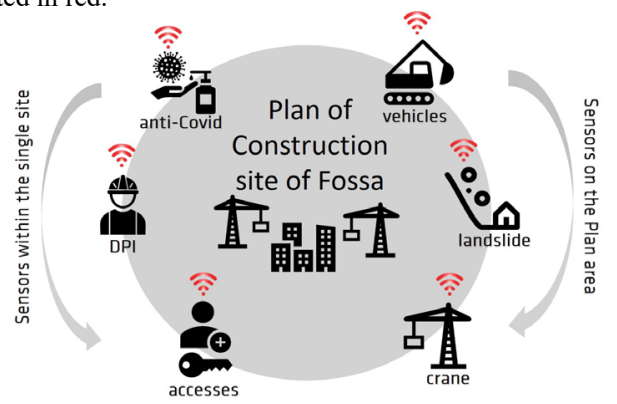

Figure 3. Monitoring via distributed sensor networks. The figure explains what wants to be monitored in the pit construction plan ${ }^{1}$.

${ }^{1}$ DPI (italian) $=$ PPE means personal protective equipment and means any equipment intended to be worn and kept by 
Radio-frequency identification (RFID) uses electromagnetic fields to automatically identify and track tags attached to objects. An RFID system consists of a tiny radio transponder, a radio receiver and transmitter. When triggered by an electromagnetic interrogation pulse from a nearby RFID reader device, the tag transmits digital data, usually an identifying inventory number, back to the reader. There are two types of RFID tags:

Passive tags are powered by energy from the RFID reader's interrogating radio waves.

Active tags are powered by a battery and thus can be read at a greater range from the RFID reader, up to hundreds of meters (figure 4).

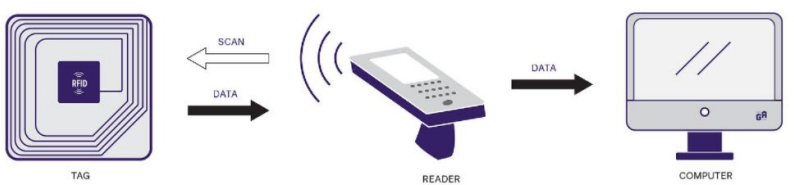

Figure 4: Reading phase of an RFID tag with an internet connected reader

RFID technology can be grouped into three frequency ranges as reported in Table 2

\begin{tabular}{|c|c|c|c|}
\hline & LF RFID & HF RFID & UHF RFID \\
\hline Frequency & $<135 \mathrm{kHz}$ & $13.56 \mathrm{MHz}$ & $865 \mathrm{MHz} \ldots 928 \mathrm{MHz}$ \\
\hline $\begin{array}{l}\text { Sensing } \\
\text { range }\end{array}$ & $<0,1 \mathrm{~m}$ & $<0,3 \mathrm{~m}$ & $<10 \mathrm{~m}$ \\
\hline Standards & $\begin{array}{c}\text { ISO11784, ISO11785 } \\
\text { (Animal identification) } \\
\text { since } 1994 \\
\text { Note: Is not offered by } \\
\text { SICK. }\end{array}$ & $\begin{array}{l}\text { ISO14443 (since } \\
2000 \text { ) } \\
\text { Note: Is not offered } \\
\text { by SICK. } \\
\text { ISO15693 (since } \\
\text { 2001) }\end{array}$ & ISO18000-63 (since 2004) \\
\hline
\end{tabular}

Table 2: Allowed frequency operation range for a RFID TAG and related standard

The WSN (Wireless Sensor Network) was designed using active and passive RFID sensors from FARSENS [33] operating in the UHF frequency range, autonomous sensors already presented by some of the authors for rockfall monitoring [28] and commercial readers from Impinj [34]. All data are collected and stored on a remote control system.
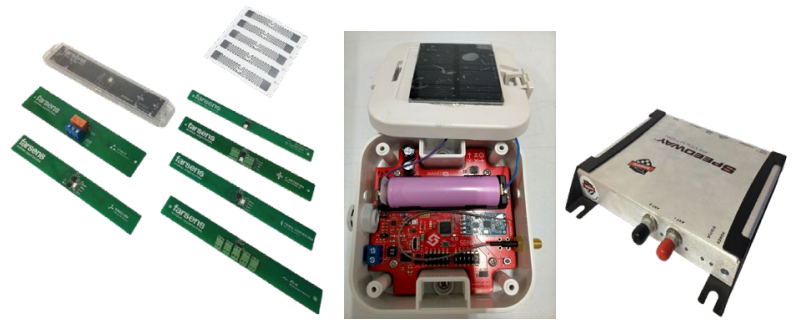

Figure 5, 6, 7: in order from left to right: RFID passive TAG from FARSENS; Autonomous sensors for Structural and Environmental Monitoring of Dynamic Events already presented in [2]; Commercial RFID reader from Impinj used in the $F$.

The different sensors are scattered in the area of the construction site and periodically send data detected by a gateway (collection point), which acquires the data, manages

the worker in order to protect him against one or more risks likely to threaten his safety or health during work. the network, and sends the collected data to another system remotely. WSN allows data collection, monitoring and surveillance of both workers and vehicles. The monitoring system as a whole consists of four basic components:
1. Distributed sensors
2. Interconnection network
3. Data collection
4. Software for data processing and control.

The WSN thus designed has several objectives:
1.
Monitoring: it can continuously track the position of workers and construction site vehicles;

2. Event detection: recognizing alarm situations and generating alerts to users.

\subsection{Criticalities to be monitored}

The following plan (Figure 8) shows the layout of the sensors making up the network.

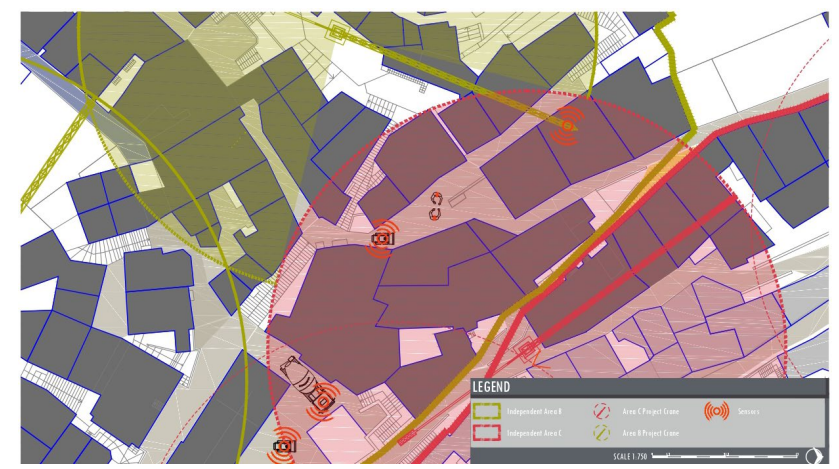

Figure 8. Sensors layout plan. The figure shows the sensors positioned on the vehicles, on the crane and on the workers.

The methodical approach of the monitoring system is based on the use of a "hardware-software" platform and foresees the evaluation of several parameters, three of which are large scale (site plan, figure 9):
1. Monitoring rockfall from Monte Circolo
2. Interference among lifting equipment
3. Construction site vehicles (overcrowding and narrow passages).

And three on a small scale (single construction site):

1. Correct use of PPE by individual workers

2. Control of construction site access

3. Control of safe distances.

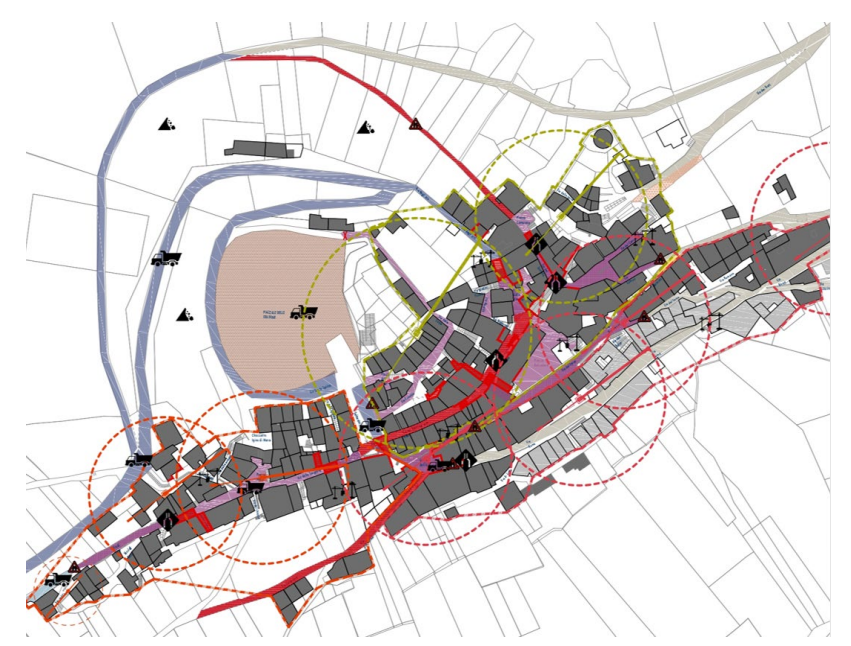




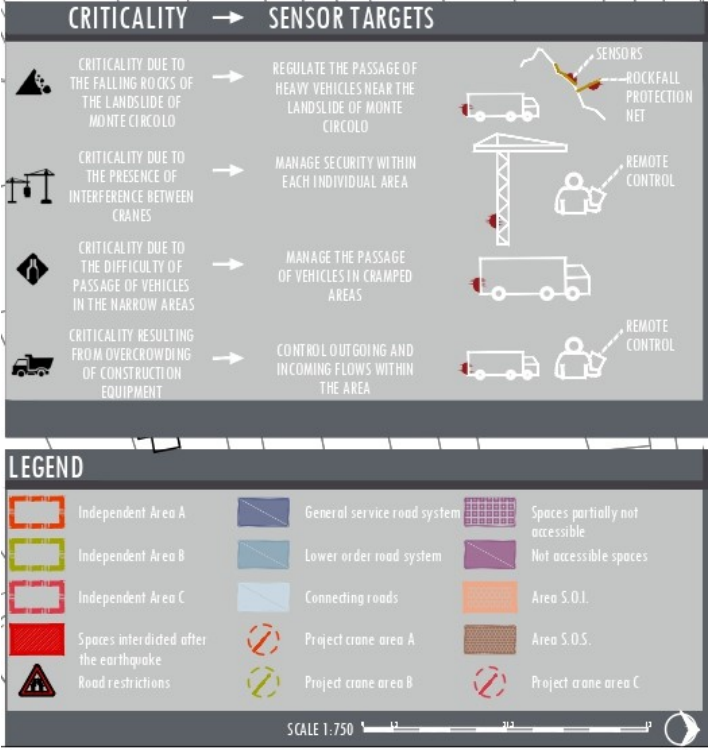

Figure 9. Map of monitoring objectives.

The sensors scattered in this way generate sound alerts to the individual user both from the vehicles and from the construction site equipment in order to prevent events that could generate accidents and therefore injuries.

The choice and the proposal of this system is also due to the simplicity of use and the immediacy of understanding and interpretation of the measures, the data collected and any alarms and management of all those operations that arise from it: from first aid to the management of situations of feared danger and prevention of accidents and injuries, even serious ones (figure $10)$.

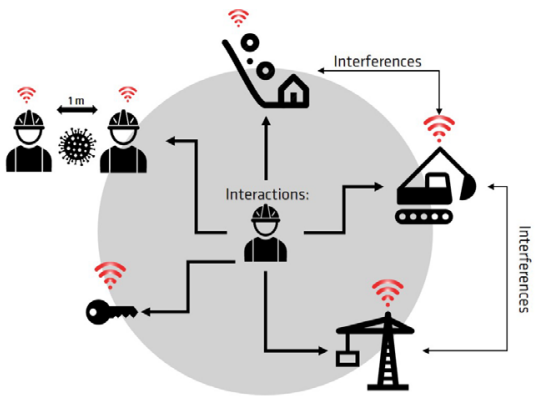

Figure 10: Interaction among sensors. The diagram represents how the worker is protected by the sensors through the interaction with the different dangers.

After identifying the main objectives to be monitored, we proceeded to identify what the unfavorable scenario was, for the purpose of construction site monitoring.

Intermediate use was taken into consideration, i.e. use in the three areas in which a number of resources and vehicles are foreseen that comes closest to reality, therefore considering the most truthful crowding possible. The time schedule of the three areas has been considered, in order to extrapolate the quantities relating to the number of workers, cranes and construction sites as the months went by.

Then, the number of workers and cranes for each area was speculated, in order to quantify the presence on site in the various months.

We then went on to define the interaction specifications, through which we can practically identify subjects, processes and places to be monitored, and finally, we established the use procedures for each of the identified specifications, in order to establish an ordered set of operations to be carried out, in order to achieve a certain purpose:
- Specifications 1-5: acoustic sound emission modulated differently by sensor is planned.

- Specification 6: it is planned to equip the worker with a bracelet to detect distance and body temperature measurement.

- Specification 7: progressive sensor-modulated acoustic sound emission is planned until the lifting device stops.

- Specification 8: it is planned for vehicles to be equipped with a sensor to locate them and detect danger, to be able to alert those who are on the same route, and to assign priority to the vehicle closest to the critical/narrow area.

- $\quad$ Specification 9: it is planned to equip vehicles with a sensor that can locate them and give priority to the heaviest vehicle.

- Specification 10: sensor-modulated acoustic sound emission is planned.

As already mentioned both RFID and full custom devices have been utilized for the sensory system design of the proposed distribute safety monitoring system. Finally, through the use of a dedicated webApp, based on a freeware commercial platform, profiling of two types of users is planned:

1. Decision-making bodies: with their administrator profiles, they can create alerts, send push notifications and communications and exchange news among the various administrators;

2. Employees: with their user profiles, they are the recipients of alerts, communications and notifications.

The main features of the App are:

- General alerts to all operators involved: all concerned parties are notified, by means of alerts, of holidays or days that the entire area will be closed due to force majeure;

- Real-time communications between the Public Administration and the competent bodies: a privileged channel of communication is established between the two aforementioned bodies, in order to exchange alerts of a cognitive, institutional nature;

- GPS mapping of the vehicles: a vehicle localization section is created for interference control;

- Reminder of compliance with Covid-19 protocol: this function has been provided in response to the spread of the global pandemic to ensure safety and prevent contagion.

We would like to specify that a training course held by the Bilateral Agency is foreseen for all the operators, but especially for the decision-making bodies, in order to manage the construction site through advanced solutions (figure 11). CREATION OF A DEDICATED APP
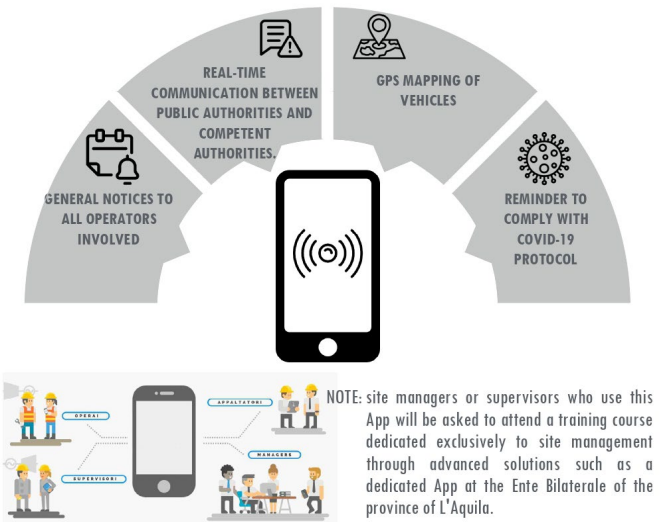

Figure 11. Dedicated App diagram. The figure illustrates what can be checked using the dedicated app, in particular news 
relating to operators (position, use of PPE, etc.), communication to the competent authorities in the event of an accident, vehicle map, anti-covid checks.

\section{REMOTE CONTROL PLAN}

In this area of particular dedication to safe construction site design, the increasingly current trend of using both wearable technologies and smart work clothes was taken into account. In reality, technology 4.0 is nothing more than the "immense" use of low cost sensors, which through interconnection return immediate and reliable information, which, appropriately managed, can predict in advance what could happen, releasing activities to prevent damage or at least warn of the possible occurrence.

The purposes are obviously aimed at reducing the risks and probability of an accident, potentially to the detriment of people, but also the immediate rescue in case of the occurrence of a harmful event, assuming that, by reducing the rescue time, the likelihood of success is increased.

A Remote Control Plan was therefore used to mitigate the risk through the application of sensors.

There are three objectives to monitor: the workers, the crane operator and the vehicles (figure 12).

\section{- Workers}

The most immediate rule is the certainty that in the work environment workers correctly and continuously use PPE, as well as all the necessary preventive measures are taken; in addition and improving what is already provided for by current regulations, this research focuses on the automation of procedures and increased efficiency of controls that probably also save time and money for the State and companies, improving the work environment, including through use of IoT systems.

Workers will be warned of danger by means of alerts, especially regarding the movement of cranes and vehicles, of overlapping work and the distance between people (safe distance for Covid19). This monitoring will be carried out both during work on the construction site and in the common areas outlined by the Construction Site Plan, such as changing rooms, canteens, healthcare facilities, offices and multi-purpose premises.

\section{- Crane operator}

In the case of the lifting device, it will emit an alert in case of interference with other cranes until forced shut-down. Crane movement will also issue alerts to workers when the base is rotating or if the operator is within its action range.

\section{IDENTIFICATION OF A STANDARD SYMBOLOGY}

\begin{tabular}{|c|c|c|}
\hline REPRESENTATION & & \\
\hline TYPE & $\begin{array}{l}\text { Sen sor to monitor specifications for } \\
\text { workers on site. }\end{array}$ & $\begin{array}{l}\text { Sen sor for checking spe cifications for } \\
\text { construction equipment. }\end{array}$ \\
\hline LOCALIZATION & $\begin{array}{c}\text { It is integrated on the } \\
\text { Personal Protective Equipment (helmet). }\end{array}$ & $\begin{array}{l}\text { It is placed on the front part } \\
\text { of the vehicle. }\end{array}$ \\
\hline SUPPLEMENT & $\begin{array}{c}\text { Batteries } \\
\text { 第 }\end{array}$ & $\underset{\rightarrow-}{\text { Wiring }}$ \\
\hline UNIT COST & $30-40 €$ & $40-50 €$ \\
\hline
\end{tabular}

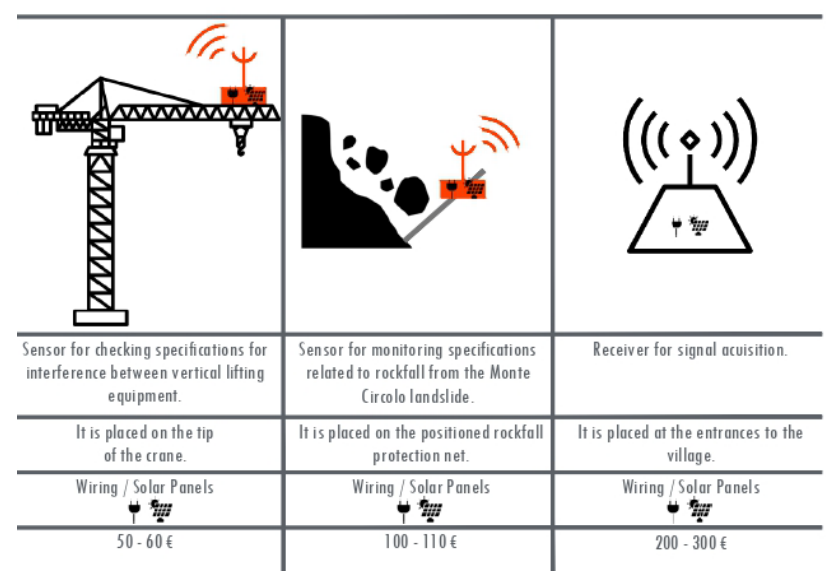

Figure 12. Schematic diagram of the sensors used. The sensors will be installed on the operator, on the vehicles, on the crane and in this particular case on the mountain to verify the fall of the rocks. All sensors will communicate with each other through a signal receiver.

\section{- Vehicles}

Vehicles, in addition to issuing alerts to workers if nearby, will be alerted if the verification of the dimensions of the roads, both in width and in height (for example an underpass such as arches) are not compatible with the dimensions of the vehicle, or if there is interference with other vehicles, or, in this case, falling rocks from the Monte Circolo landslide.

Knowing the number of users for which they are intended (workers, vehicles, vertical lifting equipment, rockfall protection nets and receivers), an estimate was made of the costs that the Public Administration will have to incur in order to guarantee safety (see table below, figure 13).

\section{HYPOTHESIS OF COST ANALYSIS}

Knowing the number of users they are intended for (workers, vehicles, vertical lifting equipment and rockfall nets), an estimate was made of the costs that the Public Administration will have to bear in order to guarantee safety, through the use of sensor technology.

\begin{tabular}{c|c|c} 
USERS & QUANTITY & COST \\
\hline WORKERS & 225 & $225 * 35 €=7^{\prime} 875 €$ \\
\hline CRANE & 10 & $10 * 55 €=550 €$ \\
\hline RECEIVERS & 2 & $2 * 250 €=500 €$ \\
\hline ROCKFALL NET & 20 & $20 * 100 €=2^{\prime} 000 €$ \\
\hline VEHICLES & 946 & $946 * 40 €=37^{\prime} 840 €$
\end{tabular}

Figure 13. Cost estimate.

Lastly, it should be noted that the overall cost of the remote control plan is the result of an overestimate, as we are still at an early stage in order to be more accurate. Specifically, the first four items are sufficiently precise to reflect reality while the last one, concerning the vehicles, represents the maximum expenditure ceiling but it could also be significantly lower. To date, however, we do not have further data for approximation.

One of the significant aspects of the Plan, from which the organization of the construction site areas derives, is the sharing of areas and equipment between the various construction sites in order to improve the efficiency and safety in the execution phase of the works. In particular, an element that particularly affects management is the shared use of the crane, which, if on the one hand it is optimal in terms of managing interference in very small areas, on the other hand it must be managed by several construction sites. At the same time and for this reason it requires greater monitoring, as well as for safety, also in terms of travel efficiency. Locating the position of the crane at all times means being able to monitor its movements and adapt the organization as quickly as possible according to the needs of individuals, simultaneously increasing the levels of safety and management. 


\section{DISCUSSION AND RESULTS}

Digitalization is a phenomenon that has involved players at all levels and in the particular Italian context is currently at the heart of the important plan called "Industry 4.0" 2016, now "Enterprise 4.0". These plans have given rise to numerous activities and initiatives aimed at automating and interconnecting industrial production. This innovation process that is investing the manufacturing sector does not also find a corresponding transformation in the construction sector, normally not very open to product and process innovation. However, it is possible to identify an incipit of change in the construction site as well, thanks to the spread of IoT and sensor technologies. In reality, this is only happening in restricted industry niches and, often, only in the realms of general or macro-enterprises. Other interesting fields of investment are data sharing platforms, in order to simplify bureaucracy and increase safety and productivity, and that of the already mentioned wearable technologies, which are now also being tested on construction sites.

However, the current initiatives are in fact highly sectoral and do not form part of a unitary process aimed at achieving a real change of mentality. They are simply realities and knowledge transferred from other areas and experimented by pioneering companies or professionals, but not supported by an internal drive within the construction world as a whole. In fact, it is based on traditional construction processes where the way companies operate is generally fragmented and competitive. This complexity and heterogeneity found in the construction process hinders the spread of digitalization and the use of simple sensor systems such as those previously illustrated. Therefore, it would be necessary to first of all invest in training and a culture of digitalization, leading to the understanding that the latter is simply a tool, not the goal to be achieved. All-round digitalization would make it possible to achieve greater quality and safety in construction as well as fluidity in the exchange of information. The methodology developed, and the case study that allowed its validation, demonstrates just that. The use of digital systems has allowed the control and coordinated management of means and human resources and has improved the construction process especially in terms of rationality, economy and safety. Furthermore, it was demonstrated how, even in the presence of high criticality, such as that caused by the pandemic crisis, it was possible to continue working safely, without risk, avoiding the paralysis of the production system that is currently causing a major economic crisis worldwide.

Research is currently in an initial state. The sensor network has been set up and will be installed on a building located in the municipality of Fossa in the construction phase.

In addition, the architecture of the sensor network relating to the monitoring of workers was also studied within the construction site itself.

\section{CONCLUSIONS}

In this paper, one of the inherent aspects in the complex world of digitalisation of the construction industry has been addressed, namely the issue of safety monitoring using a sensor system that avails of IoT. The need to develop this research arose from the need, directly encountered in the field, to automate part of the safety control systems during the post-earthquake reconstruction process. For this reason, a methodology was developed in order to monitor the vehicles and human resources, workers and crane operator, by drawing up a Remote Control Plan for risk mitigation. This methodology has been validated within the framework of the Construction Site Plan for the minor historical centre of Fossa (Aq). Thanks to the development of the case study, the absolute validity of the elaborated method was demonstrated, which allowed prediction of risk scenarios, elaboration of mitigation strategies and implementation of safety coordination, through continuous monitoring. The latter is a necessary condition for the method to be valid and up-todate.

Going into detail, it is shown how the implementation of a comprehensive and coordinated plan significantly increases safety and prevention standards, thanks to the provision of coordination mechanisms and the consideration of exogenous risks. Secondly, there is a rationalisation of economic-financial resources due to greater bargaining power, pooling of shareable resources, leading to beneficial savings and economies of scale. This leads to economic savings among all the stakeholders involved: individual companies and the Public Administration, favouring win/win strategies. Finally, it is shown how the use of technologies, such as remote management, permits to gain significant advantages: predict risk scenarios, improve coordination between resources, update the plan in real time and build a database reusable in the future.

Finally, it should be noted that the methodology developed, which proposes the use of technological innovation on the construction site, is easily exportable and replicable in other risk contexts, even post-disaster.

The topic of construction site monitoring is just one of the many areas of site digitalisation and offers many areas of study and research in which to invest. In general, it opens up unprecedented opportunities, but man must always remain the centre of technological progress, thanks to his ingenuity and inventiveness.

The construction plan has been adopted and will be considered for future construction site installations. The digitization of the single construction site is currently being studied through an internal sensor network that will dialogue with the wider system illustrated. Once the system architecture has been set, the sensors will be produced and tested on a single site to subsequently provide a broader platform that will be updated for each site change.

\section{ACKNOWLEDGEMENTS (OPTIONAL)}

Authors thank to: Municipality of Fossa (AQ); Dr. Lucio Cococcetta for reviewing the work done, as director of the ESECPT School of Construction; the technicians of the electronic laboratory of the University of L'Aquila, Stefano Ricci and Andrea Pelliccione, for the precious support during the prototype's implementation and preliminary measurements; SENSing S.r.l., a Widech Group company, spinoff of the University of L'Aquila for the rockfall sensors integration support.

\section{FUNDING}

This research has been partially funded by the "MULTIFId" Project, Fund for Sustainable Growth, Intelligent Factory Desk, D.M. 05.03.2018 Chapter III. Subjects involved: 2Bite S.r.l., Pack System S.r.1., University of L'Aquila as consultants (Department DIIIE and DICEAA).

\section{AUTHOR CONTRIBUTIONS}

P.D.B. is the scientific head of the project, he supervised and revised the text. E.L. and M.R. developed the research and B.T. the case study. E.L. elaborated the structure of the text, coordinated all contributions and wrote paragraphs 4 and 5 and par.1 and 3 together with B.T. and V.S.; V.S. revised the text and participated in sensor design. M.R. realized the literature research, wrote paragraphs 2,5 and 6 and revised the text. 


\section{REFERENCES}

[1]. Rotilio M., Laurini E., De Berardinis P. e Cococcetta L., (12 ottobre 2018), Progettare la cantierizzazione in un centro storico colpito dal sisma: un caso di studio, VI Edizione Convegno Internazionale ReUSO;

[2]. De Berardinis P., Di Giovanni G., Laurini E., Rotilio M., October 2018. Progettare l'organizzazione del cantiere di recupero nell'ambito della ricostruzione post sismica a L'Aquila. VI Edizione Convegno ReUso, Messina 11-12-13th. Gangemi Editore, Roma, ISBN: 978-88-492-3659-0.

[3]. Lucarelli M., Laurini E., Rotilio M., De Berardinis P., October 2018. Metodo BIM: gestione dei cantieri edilizi nei centri colpiti da calamità naturali. VI Edizione Convegno ReUso, Messina 11-12-13th. Gangemi Editore, Roma, ISBN: 978-88-492-3659-0.

[4]. Laurini E., Rotilio M., Lucarelli M., De Berardinis P., 2019. Technology 4.0 For Buildings Management: From Building Site To The Interactive Building Book. 2nd International Conference of Geomatics and Restoration, 8-10 May 2019, Milan, Italy.

[5]. Gazzetta Ufficiale (2009), O.P.C.M. del 6/04/2009 n 3753 "Prim interventi urgenti conseguenti agli eventi sismici che hanno colpito la provincia di l'Aquila ed altri comuni della Regione Abruzzo il giorno 6 aprile 2009

[6]. Gazzetta Ufficiale (2011), O.P.C.M. del 13/06/2011 n 3945, Ulteriori interventi urgenti diretti a fronteggiare gli eventi sismici verificatisi nella Regione Abruzzo il giorno 6 aprile 2009;

[7]. Gazzetta Ufficiale (2009), O.P.C.M. del 27/11/2009 $\mathrm{n}^{\circ} 3827$, Ulteriori interventi urgenti diretti a fronteggiare gli eventi sismici verificatisi nella Regione Abruzzo il giorno 6 aprile 2009;

[8]. Osello A. et al (2015), Building information Modelling Geografic information SistemAugmented Reality per il Facility Management, Palermo, Dario Flaccovio Editore;

[9]. Osello A e Ugliotti F.M. (2017), BIM: verso il catasto del futuro conoscere, digitalizzare, condividere, il caso studio della città di Torino, Roma, Gangemi Editore;

[10]. Libera M. (2019), BIM: industrializzazione del settore delle Costruzioni, Introduzione al Building Information Modelling Parte II;

[11]. Alicandro, M. and Rotilio, M.: UAV photogrammetry for resilience management in reconstruction plan of urban historical centres after seismic events. A case study, Int. Arch. Photogramm. Remote Sens. Spatial Inf. Sci. XLII-2/W11, 55-61, https://doi.org/10.5194/isprs-archives-XLII-2-W11-552019, 2019

[12]. Valero, E.; Adan, A.; Cerrada, C. Automatic Construction of 3D BasicSemantic Models of Inhabited Interiors Using Laser Scanners and RFID Sensors. Sensors 2012, 12, 5705-5724.

[13]. Jaselskis, E.J.; Anderson, M.R.; Jahren, C.T.; Rodriguez, Y.; Njos, S Radio-Frequency Identification Applications in Construction Industry. J. Constr. Eng. Manag. 1995, 121, 189-196.

[14]. Valero, E.; Adán, A.; Cerrada, C. Evolution of RFID Applications in Construction: A Literature Review. Sensors 2015, 15, 15988-16008. https://doi.org/10.3390/s150715988

[15]. Su, X.; Li, S.; Yuan, C.; Cai, H.; Kamat, V. Enhanced Boundary Condition-Based Approach for Construction Location Sensing Using RFID and RTK GPS. J. Constr. Eng. Manag. 2014, 140, doi:10.1061/(ASCE)CO.1943-7862.0000889.

[16]. Chae, S.; Kano, N. A Location System with RFID Technology in Building Construction Site. In Proceedings of the 22nd International Symposium on Automation and Robotics in Construction (ISARC 2005), Ferrara, Italy, 11-14 September 2005.
[17]. Ni, L.; Liu, Y.; Lau, Y.C.; Patil, A. LANDMARC: Indoor location sensing using active RFID. Wirel. Netw. 2004, 10, 701-710.

[18]. Yoon, S.; Chin, S.; Kim, Y.; Kwon, S. An Application Model of RFID Technology on Progress Measurement and Management of Construction Works. In Proceedings of the 23rd International Symposium on Automation and Robotics in Construction (ISARC 2006), Tokyo, Japan, 3-5 October 2006 .

[19]. Shiau, Y.; Tsai, J.; Cheng, S. Fire Control in Buildings and the Development of RFID Applications Systems. In Proceedings of the 24th International Symposium on Automation and Robotics in Construction (ISARC 2007), Kochi, India, 19-21 September 2007.

[20]. The Center for Construction Research and Training. The Construction Chart Book; CPWR: Silver Spring, MD, USA, 2013.

[21]. Chae, S. Development of Warning System for Preventing Collision Accident on Construction Site. In Proceedings of the 26th International Symposium on Automation and Robotics in Construction (ISARC 2009), Austin, TX, USA, 24-27 June 2009.

[22]. Wu, W.; Yang, H.; Li, Q.; Chew, D. An integrated information management model for proactive prevention of struck-by-falling-object accidents on construction sites. Autom. Constr. 2013, 34, 67-74.

[23]. Dessales, D.; Poussard, A.M.; Vauzelle, R.; Richard, N. Case Study of a Wireless Sensor Network for a Building Monitoring Application. In Proceedings of the IEEE International Conference on Green Computing and Communications, Besancon, France, 20-23 November 2012; pp. 651-654. [Google Scholar]

[24]. Barile, G.; Ferri, G.; Leoni, A.; Muttillo, M.; Pantoli, L.; Stornelli, V.; Vettori, D. Automatic Wireless Monitoring System for Real-Time Rock Fall Events. Proceedings 2017, 1, 569. [Google Scholar] [CrossRef]

[25]. Chang, C.-Y.; Hung, S.-S. Implementing RFIC and sensor technology to measure temperature and humidity inside concrete structures. Constr. Build. Mater. 2012, 26, 628-637. [Google Scholar] [CrossRef]

[26]. Murthy, S.G.N. Batteryless wireless RFID based embedded sensors for long term monitoring of reinforced concrete structures. In Proceedings of the International Symposium NDT-CE, Berlin, Germany, 15-17 September 2015; pp. 15-17. [Google Scholar]

[27]. Meng, Z.; Li, Z. RFID tag as a sensor-A review on the innovative designs and applications. Meas. Sci. Rev. 2016, 16, 305-315. [Google Scholar] [CrossRef]

[28]. Barile, G.; Leoni, A.; Pantoli, L.; Stornelli, V. Real-Time Autonomous System for Structural and Environmental Monitoring of Dynamic Events. Electronics 2018, 7, 420. https://doi.org/10.3390/electronics7120420

[29]. Schleich B., Anwer N., Mathieu L., Wartzack S., 2017. Shaping the digital twin for design and production engineering, CIRP Annals, 66(1) 141144, https://doi.org/10.1016/j.cirp.2017.04.040.

[30]. S. H. Khajavi, N. H. Motlagh, A. Jaribion, L. C. Werner and J. Holmström, "Digital Twin: Vision, Benefits, Boundaries, and Creation for Buildings," in IEEE Access, vol. 7, pp. 147406-147419, 2019, doi: 10.1109/ACCESS.2019.2946515

[31]. Stephen Cousins (2019) Data-driven construction: How the Internet of Things is changing site processes, Construction Research and Innovation, 10:4, 93-96, DOI: 10.1080/20450249.2019.1699761

[32]. El Jazzar M., Piskernik M., Nassereddine H., 2020. Digital Twin in construction: An Empirical Analysis, EG-ICE 2020 Workshop on Intelligent Computng in Engineering

[33]. http://www.farsens.com/en/ - Last accessed 18/03/2021

[34]. https://www.impinj.com/products/readers/impinj-speedway - Last accessed 18/03/2021 